\title{
ISSUES WITH EFFECTIVE DESIGN OF AN ESL TEACHER PROFESSIONAL DEVELOPMENT PROGRAMME IN SABAH, MALAYSIA
}

\author{
${ }^{1}$ WENDY HIEW \\ ${ }^{2}$ JILL MURRAY \\ ${ }^{I}$ Centre for the Promotion of Knowledge and Language Learning, Universiti Malaysia Sabah, \\ Jalan UMS, 88400 Kota Kinabalu, Sabah, Malaysia \\ wenhiew@ums.edu.my \\ ${ }^{2}$ Department of Linguistics, Macquarie University, New South Wales 2109, Australia \\ jill.murray@mq.edu.au \\ Dihantar: 21 Mei 2018 / Diterima: 24 September 2018
}

\begin{abstract}
This study investigates English as Second Language teachers' perceptions and the impact of the Professional Up-skilling of English Language Teachers programme, which was designed and conducted by the British Council Malaysia. A review of previous studies revealed a paucity of research focusing on large-scale, standardised teacher professional development programmes that involved English language teachers from both heterogeneous teaching levels (i.e. primary and secondary schools) and heterogeneous districts (i.e. urban and rural). The limited published studies available have been critical of this mode of professional development for a number of reasons, and the purpose of this study was to investigate these issues in the Malaysian context. A mixed methods explanatory sequential design was adopted, which utilised a questionnaire survey, interviews and focus group with the teachers and District English Language Officers. However, this article will focus on the qualitative findings. The findings reveal four major limitations of the programme: in the coursebook materials; negative emotional impact on the teachers, which compromised the potential benefits of the programme; selection of participants; and the amount of follow-up support. The findings have implication on programme designers and providers in designing future teacher professional development programmes.
\end{abstract}

Keywords: Teacher professional development, English language teachers, standardised program, developing country, Malaysia. 
Abstrak Kajian ini mengkaji persepsi dan impak program Professional Up-skilling of English Language Teachers yang direka dan dijalankan oleh British Council Malaysia. Kajian literatur menunjukkan terdapat kajian terhad yang menfokus kepada program pembangunan profesional guru yang seragam dan melibatkan penyertaan guru yang ramai dan bersama dari tahap berbeza (sekolah rendah dan sekolah menengah) dan daerah berlainan (bandar dan luar bandar). Kajian lepas yang terhad agak kritikal terhadap pembangunan profesional jenis mod seragam atas beberapa sebab. Kajian ini bertujuan mengkaji isu tersebut dalam konteks Malaysia. Kajian ini menggunakan kaedah gabungan penerokaan berurutan yang melibatkan soal selidik, temu duga individu dan temu duga berkumpulan bersama guru dan pegawai pendidikan daerah Bahasa Inggeris. Artikel ini akan memfokus kepada dapatan kualitatif. Dapatan kajian menunjukkan terdapat empat kelemahan dalam program tersebut dalam aspek berikut: bahan-bahan buku kursus; impak emosi kepada guru yang menyekat faedahfaedah potensi program; pemilihan peserta; dan jumlah sokongan susulan. Dapatan kajian memberi implikasi kepada pereka dan penganjur program dalam mereka program pembangunan profesional guru pada masa depan.

Kata kunci: Pembangunan profesional guru, guru Bahasa Inggeris, program seragam, negara sedang membangun, Malaysia.

\section{INTRODUCTION}

Teacher professional development programmes (PD) have undergone profound changes since the 1980's (Mundry, 2005). The programmes are based on various models, but share the intention 'to generate positive change in beliefs, skills, and behaviours' amongst teachers (Lauer, Christopher, Firpo-Triplett, \& Buchting, 2014, p. 207). Kennedy (2005) lists some common forms of teacher PD models including training, award-bearing, deficit, cascade, standards-based, coaching/mentoring, community of practice, action research and transformative. The above PD models can be applied using a traditional, reform-based or blended approach. Traditionalapproach programmes include one-size-fits-all workshops, courses, seminars 
and conferences. On the other hand, a reform-based approach programme is designed to provide subject- and need-focused programmes via study groups, teacher networking, mentoring, coaching, committees or task forces, internships, individual research projects or teacher research centres (Desimone, Porter, Garet, Yoon, \& Birman, 2002; Neale, Smith, \& Johnson, 1990; Simon \& Schifter, 1991).

The cascade model is commonly adopted by education ministries due to lower cost and greater time-effectiveness in transferring knowledge rapidly and on a large scale (Bett, 2016; Hayes, 2000; Karalis, 2016). However, some studies have shown mixed outcomes from this model. Karalis (2016) reported evidence of the effectiveness of the cascade model in Greece, where more than 20000 adult educators were trained and accredited to teach continuing vocational training activities and general adult education programmes in less than fifteen years. A majority of the participants responded very positively to the programme, rating it between 3.7 and 3.9 (out of 4.0) for their general impression and interest in the programme. In contrast, studies by Sifuna and Kaime (2007) and Mwangi and Mugambi (2013) showed that 70 per cent of Kenyan teachers who participated in the Strengthening Mathematics and Sciences in Secondary Schools (SMASSE) project had no interest in the programme because it did not meet their professional needs, and there was a lack of instructional equipment for the teachers to utilise in their classrooms. This is a common problem of the cascade model, as programmes are often conducted away from the school environment (Sifuna \& Kaime, 2007). Hayes (2000, p. 135) warns about the possible effect of the cascade model in reducing knowledge transfer 'to a trickle by the time it reaches the classroom'.

The Professional Up-skilling of English Language Teachers (ProELT), a one-year programme that was sponsored by the Malaysian Ministry of Education (MOE), was designed and conducted by the British Council for Malaysian English language teachers nationwide. The aims of the ProELT were to enhance English language teachers' language proficiency and to develop their instructional skills. The format of the ProELT included a weekly, six-hour training at a training centre plus online learning. 


\section{Standardised teacher professional development programmes: Ongoing issues}

Numerous evaluative studies on standardised English language teacher PD programmes and projects in Asia and developing countries have been reported in the literature (Balassa, Bodo'czky, \& Saunders, 2003; Dushku, 1998). The purposes of most PD programmes are to transfer skills and knowledge from the upper management to the teachers. Skills and knowledge development-based approaches are highly favoured by administrators because they are 'clearly focused, easily organised and packaged, and relatively self-contained' (Hargreaves \& Fullan, 1992, p. 3). However, these approaches have been criticised for placing little value on teachers' knowledge and experience in classroom development skills.

Studies by Dyer (1996) and Uysal (2012) on English language teacher PD projects, in India and Turkey respectively, reveal significant issues resulting from centralised development projects. For example, the $£ 250$ million Operation Blackboard project in India aimed to enhance the quality of school education and teaching methods with a shift from textbook-centred to learner-centred, by supplying a second teacher to existing single primary teachers (Dyer, 1996). The project was undertaken via a mass orientation in the form of cascade training 'with little attention to how the gap between teachers' current practice and the desired behaviour was to be narrowed' (Dyer, 1996, p. 33). As a result, some teachers rejected the teaching and learning aids due to lack of relevance to their teaching needs, poor quality, lack of explanation and strategies to implement the teachings aids by the trainers (Dyer, 1996).

Some quality issues were also identified regarding the one-week compulsory In-service Education for Teachers training for primary English language teachers in Turkey, which aimed to familiarise teachers with the new curriculum goals and teaching techniques for young language learners (Uysal, 2012). The teacher participant evaluations indicated a lack of relevance between the programme content and teachers' needs, and also a lack of discussion regarding their own problems, the material, and course evaluation (Uysal, 2012). These studies support M. Kennedy's (1988) 
argument that a top-down planning approach rarely gathers feedback from the implementers and, on the rare occasions when it does, the feedback seldom reaches the programme providers.

Several studies have documented the profound importance of programme content, which impacts teachers' knowledge and skills, and consequently student learning. Birman, Desimone, Porter, and Garet (2000), who conducted a nationwide study in the United States on 1000 teachers who participated in the Eisenhower PD Programme, argue that including content knowledge is directly related to teachers' increase in knowledge and skills. Quick, Holtzman, and Chaney (2009) examined the practices of teacher PD in San Diego, California, and their effect on 100 teachers' literacy instruction. They conclude that emphasis on teachers' understanding of subject matter over instructional strategies was more likely to improve student learning outcomes. This is because teachers must know the content of their subject area well enough to anticipate student misconceptions and engage students in learning through a wide range of instructional strategies (M. Kennedy, 1999). Shulman (1986) called this pedagogical content knowledge.

Most of the PD programmes and projects discussed above involved teachers from the same teaching level. The literature also reveals that standardised programmes and projects resulted in most of the teachers rejecting the teaching and learning aids, due to a perceived lack of relevance to their teaching needs. The current study fills a gap in the literature by examining the outcome and impact of a standardised PD programme amongst English as a Second Language (ESL) teachers from mixed teaching levels. It is also significant because it investigates a PD programme designed and conducted by an international programme provider in the context of a developing country in Asia.

This study adopts the theory of adult learning called andragogy (Knowles, 1980), as its theoretical foundation. Andragogy is defined as 'the art and science of helping adults learning', as opposed to pedagogy, which is 'the art and science of teaching children' (Knowles, 1980, p. 43). There are six principles in andragogy pertaining to adult's learning needs namely the need to know; learner's self-concept; learner's experience; readiness to learn; orientation to learning; and motivation. Knowles (1990) explains that 
adult learners need to know the reason they need to learn something and its application in their lives before undertaking a learning task (the need to know); adult are independent learners who are able to direct their learnings (learner's self-concept) as opposed to a child who is an independent learner; adult's rich experience influences their learning style and self-identify (learner's experience); adults need to be ready to learn in order to cope effectively with their real-life situations (readiness to learn); adults learn more effectively when they are able to apply their knowledge and skills to real-life situations (orientation to learning); and adults' learning needs are internally and externally motivated e.g. self-esteem and quality of life (internal) and promotions and higher salaries (external). In the present study, andragogy relates to ESL teachers' participation in a standardised teacher PD programme, who were selected based on the Cambridge Placement Test or Aptis test as opposed to voluntary participation. Andragogy guides the research in understanding whether the teacher participants' learning needs are fulfilled by the programme.

\section{The ProELT}

One of the objectives of the Malaysia Education Blueprint 2013-2025 was to enhance the quality of school teachers, specifically the language proficiency and instructional ability of ESL teachers in primary and secondary schools. The ProELT programme was developed in response to these objectives. It was designed and conducted by the British Council.

The Cambridge Placement Test (CPT) served as an assessment tool to select the first batch of ProELT participants. The test is based on the Common European Framework of Reference for Languages (CEFR) proficiency scale, which is divided into three categories of user, namely basic user (Bands A1 and A2), independent user (Bands B1 and B2) and proficient user (Bands $\mathrm{C} 1$ and $\mathrm{C} 2$ ). The $\mathrm{CPT}$ results revealed that two-thirds of the 70000 Malaysian English teachers failed to reach a proficient English level i.e. Band C ("Majority of teachers not proficient in English," 2012, September 26). The British Council selected the second cohort using its self-developed language assessment called the Aptis test, also based on the CEFR. Teachers who scored B1 and B2 were required to attend the ProELT. 


\section{METHODOLOGY}

\section{Research Design}

This study adopted a mixed methods explanatory sequential design, which utilised a questionnaire survey, interviews and focus group with the teachers and District English Language Officers. The questionnaire survey was conducted in the first phase of the study followed by interview and focus group in the second phase.

\section{Participants}

This study was conducted in Sabah, Malaysia. 1182 teachers in Sabah were selected for the ProELT, based on their CPT and Aptis test results. After participating in a quantitative study involving 350 teachers who were sampled using cluster sampling (to be reported in a forthcoming publication), ten teachers indicated their interest in participating in the follow-up focus group i.e. volunteer sampling. The individual interview and focus group data will be discussed in this article.

In addition, data were also obtained from the District English Language Officers (DELOs) who were responsible for overseeing the programme, assisting the teacher participants and trainers, and acting as intermediaries between the Education Departments and the ProELT participants and trainers. The DELOs were former experienced English language teachers who had taught in urban and rural schools. Participating DELOs were selected for inclusion based on purposive sampling, in order to ensure that the interview data from the teachers and DELOs were valid for triangulation in the data analysis stage. Tables 1 and 2 summarise the interview participants' demographic data. Their names have been changed to ensure anonymity. All of the teacher interview participants consisted of female, senior teachers who had between six and twenty-eight years of teaching experience. 
Table 1 Teacher participants' demographic data for individual interviews

\begin{tabular}{|c|c|c|c|c|c|c|}
\hline Teacher & Age & Gender & $\begin{array}{c}\text { Highest } \\
\text { Qualification }\end{array}$ & $\begin{array}{l}\text { Years of } \\
\text { Teaching }\end{array}$ & $\begin{array}{c}\text { Teaching } \\
\text { Level }\end{array}$ & $\begin{array}{c}\text { Teaching } \\
\text { Area }\end{array}$ \\
\hline Betty & 51 & $\mathrm{~F}$ & MEd TESL & 28 & Secondary & Urban $^{a}$ \\
\hline Vicky & 39 & $\mathrm{~F}$ & BEd TESL & 17 & Primary & Rural $1^{\mathrm{a}}$ \\
\hline Manjit & 49 & $\mathrm{~F}$ & MEd TESL & 23 & Primary & Rural 2b \\
\hline Tan & 38 & $\mathrm{~F}$ & BEd TESL & 14 & Primary & Urban $^{\mathrm{a}}$ \\
\hline Justina & 37 & $\mathrm{~F}$ & BA Hons. & 12 & Secondary & Urban $^{\text {a }}$ \\
\hline
\end{tabular}

${ }^{\text {a }}$ Same district as DELO 1

${ }^{\mathrm{b}}$ Same district as DELO 2

Table 2 Teacher participants' demographic data for focus group interview

\begin{tabular}{|c|c|c|c|c|c|c|}
\hline Teacher & Age & Gender & $\begin{array}{c}\text { Highest } \\
\text { Qualification }\end{array}$ & $\begin{array}{l}\text { Years of } \\
\text { Teaching }\end{array}$ & $\begin{array}{c}\text { Teaching } \\
\text { Level }\end{array}$ & Teaching Area \\
\hline Lily & 30 & $\mathrm{~F}$ & BEd TESL & 6 & Secondary & Rural 2 $^{\mathrm{b}}$ \\
\hline Farah & 38 & $\mathrm{~F}$ & BA Hons. & 10 & Primary & Rural 2 $^{\mathrm{b}}$ \\
\hline Jacqueline & 36 & $\mathrm{~F}$ & BEd TESL & 14 & Secondary & Rural $2^{b}$ \\
\hline Aidah & 45 & $\mathrm{~F}$ & BEd TESL & 18 & Primary & Rural 2 $^{\mathrm{b}}$ \\
\hline Danielle & 40 & $\mathrm{~F}$ & BA Hons. & 12 & Secondary & Rural $2^{\mathrm{b}}$ \\
\hline
\end{tabular}

${ }^{\mathrm{b}}$ Same district as DELO 2

\section{Data collection}

Our original plan was to gather only focus group data, but logistical constraints made this impossible. For this reason, five of the teachers and both DELOs were interviewed individually. Each interview and focus group lasted for about an hour. In addition to the interview data, the ProELT coursebook was examined. It contains eighteen modules including three review modules $(6,12$ and 18) and a glossary. Each module is arranged according to a theme and it is divided into eight sections, which cover language and instructional practices. The eight sections are Language, Methodology, In the Classroom, Pronunciation, Magazine, Vocabulary, Activity Page and Reflection. Primary and secondary teachers participating in the programme received the same coursebook.

\section{Data analysis}

In order to determine the breadth of its applicability, the coursebook was subjected to internal evaluation (see McDonough, Shaw \& Masuhara, 2013), 
using a table with three columns: Primary, Secondary, and Instructional Practice and Knowledge. Each item in the module was cross-checked against eleven primary and secondary level curriculum specifications namely six from Year 1 to Year 6, and five from Form 1 to Form 5. If the item was listed in the primary and/or secondary curriculum, a $(\checkmark)$ was marked under Primary and/or Secondary, and an (X) if it was not. Certain items may be relevant to teachers' instructional skill and knowledge even though they are not part of the curriculum specification. Therefore, a $(\checkmark)$ is marked under the Instructional Practice and Knowledge column. The Review and Reflection sections were excluded from this review. Thus, a total of fifteen modules were reviewed.

The analysis of the interview texts involved three types of coding techniques, namely open coding, axial coding, and selective coding (Corbin $\&$ Strauss, 2008). Full transcriptions of the data were uploaded to NVivo (a qualitative data analysis software). Open coding identified seventeen parent nodes, which were then grouped by axial coding under the macro categories of Logistical Issues: Administration of Test; Technical Issues; Views of the ProELT; and Information and Follow-up. Finally, selective coding identified the relationship between the categories, revealing three core concepts: negative impact on experienced teachers'self-esteem; flawed selection method of participants; and lack of follow-up support.

\section{FINDINGS}

\section{Lack of directly relevant programme content}

A content evaluation of the ProELT coursebook shows a lack of relevance to the curriculum syllabus.

Table 3 Review summary of the ProELT coursebook content

\begin{tabular}{|l|c|c|c|}
\hline \multicolumn{1}{|c|}{ Module Section } & Primary & Secondary & Instructional Practice and Knowledge \\
\hline Language Analysis & 4 & 10 & 3 \\
\hline Methodology & 2 & 2 & 11 \\
\hline In the Classroom & 2 & 4 & 13 \\
\hline Pronunciation & 5 & 6 & 1 \\
\hline Magazine & 2 & 4 & 12 \\
\hline Vocabulary & 1 & 3 & 2 \\
\hline Activity Page & 3 & 6 & 10 \\
\hline
\end{tabular}


As Table 3 shows, less than half out of the fifteen modules in each section except for Language Analysis (secondary level), have content that is relevant to the primary and secondary level curriculum specifications. The modules appear to be more relevant to the secondary level. However, between ten and thirteen modules in the Methodology, Activity Page, Magazine and In the Classroom sections contain activities and ideas that pertain to instructional skill and knowledge enhancement for teachers. For example, in Language Analysis (Module 4) time expression, 'By the time...' is not explicitly taught in either teaching levels, but teachers can incorporate this knowledge into their lessons as a useful writing guide for their students.

Responses from the teachers in the interviews and focus group were triangulated with the findings from the coursebook evaluation. In general, the teachers found the coursebook to be unsuitable for their students' learning level due to a lack of relevance to the curriculum. For example, Manjit, who teaches primary level, explains that most of the materials did not relate to the textbook syllabus:

Most of them I find are more applicable to the secondary level. It's more like 20 per cent for the primary and the rest 80 per cent more to the secondary school.

Betty, who teaches Form 1 (Year 7) and Form 6 (Years 12 and 13), described the challenge of adapting the standardised ProELT materials:

It takes time to adapt and plan. You can't use the same activities again. You want to adapt and change the module to suit your students. Of course, I cannot teach the way I teach Form 6 to my Form 1 students.

In addition, Betty noted that Form 6 students are required to take the Malaysian University English Test, and that the ProELT materials were not relevant to her students' learning needs. Meanwhile, Justina who teaches secondary level thought that 'the material is general' across primary and secondary levels. As a result of the standardised teaching materials and their lack of relevance to the syllabus, the majority of the teachers revealed that they did not actually apply any of the programme resources in their lessons. This was a somewhat discouraging outcome. Only two teachers, Justina and Tan, stated they had adapted some of the ProELT materials. 
The responses from the DELOs supported the teachers' mixed views regarding the programme content. For example, Margaret reported the conflicting feedback that she received from the primary and secondary school teachers:

Some of the [primary school] teachers told me that they feel the strategies, the ideas, the materials are more suitable for the secondary school. But some [secondary school] teachers told me that the materials are suitable for the primary school.

She explained that the materials were not designed to be adopted directly into the lessons but were to train the teachers to think creatively, in order to 'come up with new ideas' to adapt the materials according to their students' learning needs and language proficiency level. The creativity objective did not seem to be understood by the teachers, whose responses indicated they were more likely to expect the activities to be directly applicable. The DELOs did not demonstrate any sense of responsibility for the quality of the teaching materials. For example, Alex explained that the programme providers i.e. English Language Teaching Centre and the British Council would have to be the ones to review the materials. He added that as DELOs, 'we are just monitoring [the programme]'.

These findings suggest that the ProELT coursebook served more as a generic resource book, as opposed to being uniquely designed for the programme. The findings pointed to the conclusion that a more contextually-sensitive design may have given rise to materials that catered more effectively to the instructional and learning needs of the teachers.

\section{Negative impact on experienced teachers' self-esteem}

Three main themes emerged from the analysis of the teachers' responses to being selected for the ProELT. These were:

1. reduced self-confidence;

2. feeling embarrassed;

3. feeling inferior and demotivated. 
The ProELT is perceived by many participants as a training for linguistically unskilled and instructionally incompetent teachers. Eight out of ten participants experienced a loss of face at being selected for the ProELT because they had been regarded as English language experts by their colleagues and administrators. These effects and their consequences will be discussed below and representative extracts provided. The examples are taken from the interview and focus group data.

One teacher who experienced a reduction in self-confidence is Lily, who felt that being selected for the ProELT denoted her as being an incompetent teacher. She explained that participating in the ProELT had 'really turned me down as an English teacher'. Prior to the training, she 'felt more confident' with her teaching but reported 'now I don't feel confident, because I know I'm not good enough.'

One example of a teacher who initially felt embarrassed being selected for the ProELT is Justina, who was worried about her colleagues' negative perception about her teaching capability. Justina explained she felt 'quite embarrassed' because she thought her colleagues perceived her as 'not capable of teaching English' because she 'didn't achieve the expected grade [in the Aptis test]'. Another example of this feeling was also expressed by Lily who felt embarrassed and upset because she thought 'maybe I am not good enough' to teach.

Only one teacher, Tan, reported that she was 'very happy' to be selected for the ProELT. Negative effects on motivation were reported from the rest of the samples, and these were commonly linked to a sense of inferiority at being singled out to participate. One teacher who felt inferior and demotivated is Farah, who was judged by her colleagues because of her average Aptis test result and for being selected for the ProELT. Farah, who has been teaching primary school students in the rural district for ten years, felt she was 'not suitable to teach' and 'not even a good English teacher' as a result of the Aptis test. 
The examples cited in these three interrelated areas are typical of the group, who reported that being selected for the ProELT was negatively perceived by most of the teachers and their colleagues, and that it had impacted their reputation and self-esteem.

\section{Flawed selection method of participants}

Three out of ten senior teachers directly attributed the self-esteem and motivational issues to the selection method of the ProELT participants. As discussed above, the ProELT had two objectives namely 1) to enhance the teachers' language skill, and 2) to enhance the teachers' instructional skill. The selection was based solely on the CPT and Aptis test, which focused on language skills; there was no instrument to assess instructional skills. As a result, the aforementioned senior teachers experienced some distress because their experience and postgraduate qualification were disregarded during the selection process.

A typical example is Vicky who said she felt 'a bit degraded' when her colleagues discovered she was selected for the ProELT. She had seventeen years of teaching experience and is a well-known trainer, educator, and adjudicator among the English language teaching community in her rural school district. Vicky recalled the participants' responses to seeing her at the training, 'I cannot believe she's attending this course. Really? What actually she got [in the Aptis test]?'

Another example of this feeling was expressed by Betty who has an MEd in TESL and is the most senior teacher amongst the interview participants with 28 years of experience. She also felt her status had been degraded because her master's degree did not gain her an exemption from the ProELT. She thought her postgraduate qualification would have proven her teaching and language capabilities.

In response, DELO Margaret was sympathetic to the teachers and reported that she tried 'to comfort the teachers so that they won't feel demotivated.' She acknowledged the teachers' experiences and expertise, and attributed their low and average CPT and Aptis test scores to 'some other 
problems or technical problems.' Margaret explained that the teachers had the option to apply for an exemption from the ProELT through the MOE. However, although this option was available, Betty was hesitant to take it up because she was worried that the Ministry 'might even blacklist me for going against their instruction [to attend the ProELT].'

Thus, these findings suggest the ProELT's approach to assessing and selecting suitable participants was highly problematic. The CPT and Aptis tests could be justified as being suitable for assessing language proficiency, but an additional assessment procedure was necessary to assess the teachers' instructional skill.

\section{Lack of follow-up support}

The ProELT did not provide follow-up support for the teachers in the form of classroom observations, visits, or meetings. Some teachers suggested classroom observation would be a possible useful addition, but there were mixed views among the interview participants.

Teachers who advocated observation reasoned that it would allow the trainer to understand their teaching and students' learning challenges. For example, Manjit, who teaches in a village, has thirty-eight students in a small classroom who are '[sitting] wall-to-wall'. She lamented, 'If I want to do group work, I cannot move them around.' Without a classroom observation, Manjit doubted the effectiveness of conducting teaching practice among teachers in the training, because it did not simulate an actual classroom context with 'real students who can't speak and understand English'.

The preference for an observation component was not unanimous. Tan expressed her concerns that there might be pressure 'to perform better than normal' during a teaching observation. Similarly, Justina expressed feeling stressed and uncomfortable, because 'it's not like your colleague [who is observing]. So, there'll be extra tension [to perform well]'.

Most of the teachers who agreed to being observed by their trainer had set one condition: the trainer should be familiar with the Malaysian 
curriculum specifications, with local knowledge of the learning objectives and outcomes, and activities.

DELO Margaret agreed that the trainers should conduct classroom observations. She managed to conduct a few classroom observations at her own initiative in her urban district. As for Alex, he also agreed that classroom observations should be part of a follow-up support so that the trainers 'can see the effectiveness of the activities that the teachers have learned from the ProELT. It's a good opportunity for them to discuss any problems with the lessons and activities.'

These responses highlight the need for further consideration of the inclusion of classroom observations, in order to ensure successful implementation of the programme materials, as opposed to being an assessment. It also highlighted the need for these to be undertaken in a supportive and culturally appropriate way by people with a knowledge of contextual constraints.

The responses from Jacqueline, Aidah, and Danielle were similar to the other focus group participants, but mostly in brief responses in regard to the aforementioned four major findings. Therefore, their names were not mentioned in the findings because their responses were summarised accordingly. On the other hand, some participants who gave distinct responses have been highlighted. This helps to clarify the reason the findings from Jacqueline, Aidah, and Danielle are not mentioned here.

\section{DISCUSSIONS}

\section{Lack of directly relevant programme content}

Two reasons could be suggested to explain the lack of relevance and overstandardisation of the ProELT content: the programme designers did not conduct a teachers' needs assessment nor did they include teachers in the decision-making and design processes of the content. 
Needs assessment is crucial to identify the gaps between current and desired proficiencies (Galbraith, 1990). This is necessary to maximise the coherence between the programme content and teachers' needs (Waters \& Vilches, 2012), and to select appropriate topics and materials (Knox, 1986). The effect of the programme provider's failure to conduct a needs assessment was evident in the present study, in which it was noted that the ProELT was a 'waste' for one participant (Betty), because it was similar to a refresher course on teaching methodology for trainee or novice teachers, and the grammar items were too basic. Vicky shared Betty's views, and she felt demotivated and had no desire to continue with the one-year programme. These findings are consistent with Guskey's (2000) point that effective PD takes account of teachers' life stages and career development, and also Ausubel, Novak and Hanesian's (1978) emphasis on the importance of ascertaining learners' prior knowledge.

The second reason pertains to the lack of teachers' involvement in the decision-making and design processes of the programme content. As the end-users, teachers are in a better position than the programme instructors to determine how the innovation should be implemented (Uysal, 2012), to describe their own problems and situations, and to share their expertise (Bax, 1997). The inclusion of teachers creates a 'context-sensitive approach' (Bax, 1997, p. 233), which gives priority to teachers' existing experiences and local classroom context. This approach bridges the gap between the adoption of teaching methodologies in the programme and teachers' instructional realities (Uysal, 2012), and reduces teachers' anxiety and fear of change (Craig, Kraft, \& du Plessis, 1998).

\section{Negative impact on experienced teachers' self-esteem}

Over the years of their career, experienced teachers build their self-esteem in what Lerner (1985) terms 'earned' self-esteem. It is based on 'learning to tolerate frustration and delay, to care for others, to work hard, and to persevere in the face of obstacles' (Juhasz, 1990, p. 238).

In this study, the participating teachers had been teaching between six and 28 years and had regarded their teaching competency, and career 
and academic achievements with high self-esteem. However, nine out of the ten teachers reported experiencing lower self-esteem e.g. lesser confidence, and feeling demotivated, degraded, and inferior, due to being selected for the ProELT. This finding is consistent with Knowles's (1984) Adult Learning Theory, which states that teachers with more experience have different learning needs than younger adult learners with less experience. Day (1999) argues that PDs that often disregard the concerns of individual participants and make little effort to relate their learning experiences to workplace conditions have little impact upon them. This is the reason PD programmes should be linked to teachers' practice by carefully and precisely analysing their learning and PD needs (Craft, 2002) and also the needs of their students (Craft, 2002; Edelfelt, 1977), in order to ensure effective implementation of teachers' PD learning in their lessons (Loucks-Horsley, Stiles, Mundry, Love, \& Hewson, 2010).

\section{Flawed selection method of participants}

The selection of programme participants must be carefully undertaken by the programme designers, in order to ensure a 'match' between the participants' needs and programme objective and content. In the present study, there was a misalignment between the single selection method and the two objectives of the ProELT, which targeted language and instructional skills. The sole use of language proficiency assessment resulted in dissatisfaction among the interview participants, particularly experienced teachers, who felt that they were unfairly selected without an appropriate assessment of their instructional skill. Hayes, Chang, and Imm (2011) argue that teacher evaluation is multifaceted, which also involves views from various stakeholders and the teachers' own self-reflection, as opposed to a summative or single evaluation. The current selection procedure ignores such research.

\section{Lack of follow-up support}

Education researchers highly recommend classroom visits and lesson observations as follow-up strategies, in order to assist teachers in transferring and implementing new skills, activities, and innovations in the classroom 
(Hayes, 1995, 2000; M. J. Kennedy, Rodgers, Romig, Lloyd, \& Brownell, 2017). In the present study, there was no follow-up from the trainers or MOE during and after the completion of the ProELT. Through follow-up support, the trainers would have been more aware of the teachers' issues in implementing the programme resources in their lessons and provided advice to overcome the issues of implementation (Hayes, 1995).

O'Sullivan (2002) cautions that follow-up should preferably be conducted among a smaller number of teachers, in order to provide them with more effective coaching as opposed to a larger number. In the case of the ProELT, the less experienced participants may be more in a position to benefit. Second, the weekly training allows teachers to trial the teaching techniques with their students. The teachers could discuss with their trainer any issues with the implementation in the following training session (Peacock, 1993). Therefore, this weekly discussion might be effective as a follow-up in lieu of classroom visits.

Despite the four significant weaknesses identified by our research, it does not lead to the conclusion that the programme was a complete failure. The ProELT deserves fair acknowledgement for its partial success in promoting changes in teachers' practice and developing instructional knowledge and language skill in some of the participants. However, as a nationwide, MOE-sponsored programme, it was evident that the Ministry's top-down mandates and goals played a dominant role in the ProELT, as opposed to the teachers' needs.

\section{IMPLICATIONS AND RECOMMENDATIONS}

The findings from this study have implications for the programme providers (i.e. programme funders) and programme designers in this specific case investigated, but also in comparable situations throughout the profession. 


\section{Programme providers}

\section{A. Method for selecting participants}

Findings from the present study demonstrate a need for programme designers to adopt valid methods for selecting participants that align with the programme objectives. For example, if the programme objective is to enhance specific subject-matter or pedagogical knowledge, the programme providers need to identify and select the targeted teacher group via voluntary participation or to conduct teaching observations and interviews with the teachers. It can be argued that the latter option is impractical for largescale, nationwide programmes, because it is time-consuming and requires substantial human resource allocation to visit every school. However, this could be managed by more effective targeting of participants and by delegating the responsibility to the school leaders or Head of English Units.

Based on the issues arising in the case of the ProELT, programme designers need to be very cautious in deciding the most fitting selection procedure for the teachers. As it is not ideal to focus on teachers' language proficiency and instructional skill in the same programme, and also challenging to select participants who stand to benefit from both components, it could be advisable for the programme designers to conduct two separate programmes so that the selection of participants could be undertaken using a more valid procedure.

\section{B. Teachers' needs assessment}

The present study showcases the feelings of experienced teachers who were frustrated being selected for the ProELT, which was irrelevant to their professional needs. It is crucial that programme designers conduct teachers' needs assessment, in order to identify the needs of the teachers. Ideally, the needs assessment should include the six principles of andragogy that pertains to adult's learning needs namely the need to know; learner's selfconcept; learner's experience; readiness to learn; orientation to learning; and motivation. The theory of andragogy has been explained in the Introduction section of this paper. An example of the adoption of teachers' needs assessment 
in a teacher professional development programme is a study by Murphy and de Paor (2017) who conducted an online survey on needs analysis among 591 educational professional prior to the development of the National Institute for Studies in Education in the Republic of Ireland. The survey revealed exactly the kinds of similarities and differences in the priorities of primary and secondary school teachers. In addition, needs assessment should also be conducted throughout the programme to allow for necessary adjustments, in order to ensure that the learners and programme goals are met; by the end of the programme, it can be used for assessing progress and also for planning future directions for the learners and programme (Orlich, 1983).

\section{Programme designers}

\section{A. Programme content}

It is recommended that the programme designers prepare separate programmes for the primary and secondary levels and focus on teachers' understanding of subject matter and pedagogical content knowledge, as opposed to generic learning. A separate programme is crucial due to the distinct teaching and learning approaches between young learners (primary level), and teenagers and young adults (secondary level). This ensures that teachers gain better understanding of what they teach and how students acquire specific content knowledge and skill (Guskey \& Yoon, 2009). One example of this is the School Attuned Programme designed by Broad and Evans (2006), a highly regarded PD programme that involved educators from Kindergarten to Grade 12. It contained two separate curriculums for Kindergarten to Grade 8, and Grades 7 to 12 teachers to cater to the diverse learning needs of students.

\section{B. Inclusion of teachers in decision-making and programme planning}

Our findings indicate that the lack of relevance of the programme content could have been avoided if the programme designers had included teachers in the preliminary and ongoing planning of the ProELT. This is consistent with Gray's (1989) view of the negative outcomes that arise when teachers are excluded from decision-making processes. As one of the main 
stakeholders, it is crucial that teachers have some agency in selecting the goals and activities, evaluating the programme, and providing feedback on necessary adjustments while the programme is ongoing (Orlich, 1983). An example is the Challenge 2000 Multimedia Project, which focused on the use of technology in student project-based learning activities (Broad \& Evans, 2006). 150 teachers were given autonomy to design the content and skill focus for their projects according to their relevant contexts, such as the learning focus of selected software. They were provided with mentoring, support, and mini-grants to purchase specialised equipment.

Guskey (2000) argues that teachers' involvement in a programme's development increases their specific knowledge and skills, and their ability to work collaboratively. This results in teachers experiencing 'strong interest in the problems and issues addressed, and, hence are personally committed to finding workable solutions... [which are] more likely to succeed' (Guskey, 2000, p. 25). This aligns with Barth's (1990) earlier claim that teachers are less committed to a programme goal when they are not involved in the decision-making process of the programme.

\section{CONCLUSION}

The qualitative study of the ProELT programme relied on a relatively small number of participants, but this has been advantageous in that it allowed their experiences to be investigated in considerable depth and detail. As mentioned earlier in the Methodology section (see Participants sub-section), the quantitative findings will be reported in a forthcoming publication. By triangulating the teacher and DELO perspectives, and also the content of the course and the teaching syllabus materials we highlighted some significant pitfalls which impacted on the success of the programme, and which we have argued can be applied in other contexts. Implications for overcoming these obstacles in future PD programme design have been discussed and recommendations made. It is worth bearing in mind, however that the success and failure of a teacher PD programme in any context does not depend only on theory or policy, but on the joint effort, accountability and responsibility of multiple stakeholders who fund, design, deliver, implement, receive and support the innovation. 


\section{ACKNOWLEDGEMENT}

This completed doctorate research was sponsored by the Malaysian Ministry of Higher Education, Universiti Malaysia Sabah and funded by Macquarie University.

\section{REFERENCES}

Ausubel, D. P., Novak, J. D., \& Hanesian, H. (1978). Educational psychology: A cognitive view (2nd ed.). New York, NY: Holt, Rinehart and Winston.

Balassa, K., Bodo'czky, C., \& Saunders, D. (2003). An impact study of the national Hungarian mentoring project in English language training. Mentoring \& Tutoring: Partnership in Learning, 11 (3), 307-320. https:// doi.org/10.1080/1361126032000138346

Barth, R. S. (1990). Improving schools from within: Teachers, parents, and principals can make a difference. San Francisco, CA: Jossey-Bass.

Bax, S. (1997). Roles for a teacher educator in context-sensitive teacher education. ELT Journal, 51 (3), 232-241. https://doi.org/10.1093/elt/51.3.232

Bett, H. K. (2016). The cascade model of teachers' continuing professional development in Kenya: A time for change? Cogent Education, 3, 1-9. https:// doi.org/10.1080/2331186X.2016.1139439

Birman, B. F., Desimone, L., Porter, A. C., \& Garet, M. S. (2000). Designing professional development that works. Educational Leadership, 57 (8), $28-33$.

Broad, K., \& Evans, M. (2006). A review of literature on professional development content and delivery modes for experienced teachers. Ontario, Canada: University of Toronto.

Corbin, J., \& Strauss, A. (2008). Basics of qualitative research: Techniques and procedures for developing grounded theory. London, England: SAGE.

Craft, A. (2002). Continuing professional development: A practical guide for teachers and schools (2nd ed.). London, England: Routledge.

Craig, H. J., Kraft, R. J., \& du Plessis, J. (1998). Teacher development: Making an impact. Washington, DC: World Bank.

Day, C. (1999). Developing teachers: The challenges of lifelong learning. London, England: Falmer Press.

Desimone, L. M., Porter, A. C., Garet, M. S., Yoon, K. S., \& Birman, B. F. (2002). Effects of professional development on teachers' instruction: Results from a three-year longitudinal study. Educational Evaluation and Policy Analysis, 24 (2), 81-112. https://doi.org/10.3102/01623737024002081 
Dushku, S. (1998). ELT in Albania: Project evaluation and change. System, 26 (3), 369-388. https://doi.org/10.1016/S0346-251X(98)00024-4

Dyer, C. (1996). Primary teachers and policy innovation in India: Some neglected issues. International Journal of Educational Development, 16 (1), 27-40. https://doi.org/10.1016/0738-0593(94)00046-5

Edelfelt, R. A. (1977). Inservice education: Criteria for and examples of local programs. Bellingham, Washington, DC: Western Washington State College.

Galbraith, M. W. (1990). Adult learning methods. Malabar, FL: Krieger.

Gray, B. (1989). Collaborating: Finding common ground for multiparty problems. San Francisco, CA: Jossey-Bass.

Guskey, T. R. (2000). Evaluating professional development. Thousand Oaks, CA: Corwin Press.

Guskey, T. R., \& Yoon, K. S. (2009). What works in professional development. Phi Delta Kappan, 90(7), 495-500. https://doi.org/10.1177/003172170909000709

Hargreaves, A., \& Fullan, M. (1992). Understanding teacher development. New York, NY: Teacher College Press.

Hayes, D. (1995). In-service teacher development: Some basic principles. ELT Journal, 49 (3), 252-261. https://doi.org/10.1093/elt/49.3.252

Hayes, D. (2000). Cascade training and teachers' professional development. ELT Journal, 54 (2), 135-145. https://doi.org/10.1093/elt/54.2.135

Hayes, D., Chang, K., \& Imm, C. (2011). Research and practice in language teacher evaluation. English Teaching, 66 (1), 179-199.

Juhasz, A. (1990). Teacher self-esteem: A triple role approach to this forgotten dimension. Education, 111 (2), 234-241.

Karalis, T. (2016). Cascade approach to training: Theoretical issues and practical applications in non-formal education. Journal of Education \& Social Policy, 3 (2), 104-108.

Kennedy, A. (2005). Models of continuing professional development: A framework for analysis. Journal of In-Service Education, 31 (2), 235-250.

Kennedy, C. (1988). Evaluation of the management of change in ELT projects. Applied Linguistics, 9 (4), 329-342. https://doi.org/10.1093/applin/9.4.329

Kennedy, M. (1999). Form and substance in Mathematics and Science professional development. NISE Brief, 3 (2), 2-9.

Kennedy, M. J., Rodgers, W. J., Romig, J. E., Lloyd, J. W., \& Brownell, M. T. (2017). Effects of a multimedia professional development package on inclusive science teachers' vocabulary instruction. Journal of Teacher Education, 68 (2), 213-230. https://doi.org/10.1177/0022487116687554

Knowles, M. S. (1980). The modern practice of adult education: From pedagogy to andragogy. Englewood Cliffs, NJ: Cambridge.

Knowles, M. S. (1984). Andragogy in action: Applying modern principles of adult education. San Francisco, CA: Jossey-Bass. 
Knowles, M. S. (1990). The adult learner: A neglected species (4th ed.). Houston, TX: Gulf Publishing.

Knox, A. B. (1986). Helping adults learn: A guide to planning, implementing, and conducting programs. San Francisco, CA: Jossey-Bass.

Lauer, P. A., Christopher, D. E., Firpo-Triplett, R., \& Buchting, F. (2014). The impact of short-term professional development on participant outcomes: A review of the literature. Professional Development in Education, 40 (2), 207-227. https://doi.org/10.1080/19415257.2013.776619

Lerner, B. (1985). Self-esteem and excellence: The choice and the paradox. American Educator, 9 (4), 10-16.

Loucks-Horsley, S., Stiles, K. E., Mundry, S., Love, N., \& Hewson, P. W. (2010). Designing professional development for teachers of science and mathematics (3rd ed.). Thousand Oaks, CA: Corwin Press.

Majority of teachers not proficient in English. (2012, September 26). The Star Online. Retrieved from http://www.thestar.com.my/news/nation/2012/09/26/ majority-of-teachers-not-proficient-in-english/

McDonough, J., Shaw, C., \& Masuhara, H. (2013). Materials and methods in ELT (3rd ed.). Sussex, England: Wiley.

Mundry, S. (2005). Changing perspectives in professional development. Science Educator, 14 (1), 9-15.

Murphy, T. R. N., \& de Paor, C. (2017). Teachers' CPD and sectoral interests: Opportunities for convergence and divergence. Teaching and Teacher Education, 66, 242-249. https://doi.org/10.1016/j.tate.2017.04.018

Mwangi, N. I., \& Mugambi, M. (2013). Evaluation of strengthening of mathematics and science in secondary education (SMASSE) program: A case study of Murang'a south district, Kenya. International Journal of Education Learning and Development, 1 (1), 46-60.

Neale, D. C., Smith, D., \& Johnson, V. G. (1990). Implementing conceptual change teaching in primary science. The Elementary School Journal, 91 (2), 109-131. https://doi.org/10.1086/461641

O’Sullivan, M. C. (2002). Effective follow-up strategies for professional development for primary teachers in Namibia. Teacher Development, 6 (2), 181-203. https://doi.org/10.1080/13664530200200164

Orlich, D. C. (1983). Some considerations for effective in-service education. The Clearing House, 56 (5), 197-202. https://doi.org/10.1080/00098655.1983 .10113772

Peacock, A. (1993). The in service training of primary teachers in science in Namibia. Journal of In-Service Education, 19 (2), 21-26. https://doi. org/10.1080/0305763930190205 
Quick, H. E., Holtzman, D. J., \& Chaney, K. R. (2009). Professional development and instructional practice: Conceptions and evidence of effectiveness. Journal of Education for Students Placed at Risk, 14 (1), 45-71. https:// doi.org/10.1080/10824660802715429

Shulman, L. S. (1986). Those who understand: Knowledge growth in teaching. Educational Researcher, 15 (2), 4-14. https://doi. org/10.3102/0013189X015002004

Sifuna, D. N., \& Kaime, J. G. (2007). The effect of in-service education and training (INSET) programmes in mathematics and science on classroom interaction: A case study of primary and secondary schools in Kenya. Africa Education Review, 4, 104-126. https://doi.org/10.1080/18146620701412191

Simon, M. A., \& Schifter, D. (1991). Towards a constructivist perspective: An intervention study of mathematics teacher development. Educational Studies in Mathematics, 22 (4), 309-331. https://doi.org/10.1007/BF00369293

Uysal, H. H. (2012). Evaluation of an in-service training program for primary-school language teachers in Turkey. Australian Journal of Teacher Education, 37 (7), 14-19. http://dx.doi.org/10.14221/ajte.2012v37n7.4

Waters, A., \& Vilches, M. L. C. (2012). 'Tanggap, tiklop, tago'(receive, fold, keep): Perceptions of best practice in ELT INSET. British Council ELT 12 (1), 1-36. 
